Check for updates

Cite this: RSC Adv., 2018, 8, 15897

\title{
Performance and mechanism of free nitrous acid on the solubilization of waste activated sludge
}

\author{
Jinsong Wang, ${ }^{\text {ab }}$ Zhaoji Zhang, (D) *a Xin Ye, ${ }^{a}$ Fuyi Huang ${ }^{a}$ and Shaohua Chen*a \\ Free nitrous acid (FNA) is a promising chemical reagent for excess sludge reduction. The distinctive \\ properties of FNA treatment on waste activated sludge (WAS) disposal have previously been \\ demonstrated, however, the cellular response, permeabilization, and disruption caused by low- \\ concentration FNA and the direct cell solubilization of WAS using concentrated FNA should be better \\ understood. In this study, the parameters that influence the sludge solubilization efficiency were \\ optimized over a wide range of FNA concentrations. The sludge solubilization efficiency was found to be \\ superior when the sludge was exposed to FNA (when the dosage of $\mathrm{NaNO}_{2}$ was $0.12 \mathrm{~g} \mathrm{~g}^{-1} \mathrm{TSS}_{\text {and }}$ the \\ $\mathrm{pH}$ was 3.0, $\mathrm{FNA}=20.94 \mathrm{mg} \mathrm{L}{ }^{-1}$ ) for $10 \mathrm{~h}$ at $25^{\circ} \mathrm{C}$, and the TSS removal and COD dissolution \\ efficiencies were found to be prominent at $38 \%$ and $7 \%$, respectively. In the FNA treatment of WAS, \\ some FNA-tolerable cells increased the $\mathrm{K}^{+}, \mathrm{Ca}^{2+}$, and $\mathrm{H}^{+}$effluxes under low concentrations of FNA, and \\ finally achieved ion homeostasis based on the results using a scanning ion-selective electrode \\ measurement technique. This could cause the cells in WAS to maintain cytoactivity and integrity under \\ a low-concentration FNA treatment. Furthermore, flow cytometry was used to assess the \\ permeabilization and disruption of sludge cells toward a concentration gradient of FNA. Flow cytometry \\ results indicated that cells in sludge flocs were disrupted within 30 minutes when the FNA concentration \\ was above $8 \mathrm{mg} \mathrm{L}^{-1}$.
}

Received 5th March 2018 Accepted 17th April 2018

DOI: 10.1039/c8ra01951g

rsc.li/rsc-advances ozonation, solar photocatalysis, ${ }^{\mathbf{1 0}}$ and potassium ferrate oxidation $^{\mathbf{1 1}}$ are currently receiving significant attention. Moreover, a novel chemical approach for reducing sludge production in WWTPs using free nitrous acid (FNA) has been established due to its strong biocidal and permeabilization effects on activated sludge cells. ${ }^{12}$ In the WWTP bioprocess, FNA, as a by-product, can be produced in situ through the nitritation of anaerobic digestion liquor. ${ }^{\mathbf{1 3 , 1 4}}$ In addition, FNA, which is the protonated form of nitrite, has been long thought to be responsible for the microbial metabolism inhibition of many functional bacteria (e.g., nitrifiers, denitrifiers, and polyphosphate-accumulating organisms (PAOs)). ${ }^{15}$ Thus, recently, the FNA treatment of sludge has been considered an effective and economic way to reduce the sludge production ${ }^{16}$ and $\mathrm{N}_{2} \mathrm{O}$ emission ${ }^{17}$ of WWTPs, enhance the secondary sludge biodegradability ${ }^{\mathbf{1 8}}$ and nutrient removal, ${ }^{19,20}$ and advance methane ${ }^{21}$ and short-chain fatty acid production..$^{22,23}$

The unique properties of FNA treatment on WAS disposal have been demonstrated; however, the inhibition mechanism and cellular response toward low-concentration FNA remain inconclusive. Sijbesma et al. ${ }^{24}$ have found that FNA can act as a protonophore to inhibit the ATP synthesis of Pseudomonas fluorescens. Park ${ }^{25}$ discovered that FNA could react directly with sulfhydryl-containing enzymes and affect the tricarboxylic acid (TCA) cycle. Other researchers have confirmed that the effect of FNA stress on bacteria can be ascribed to the release of nitrogen
${ }^{a}$ Key Laboratory of Urban Pollutant Conversion, Institute of Urban Environment, Chinese Academy of Sciences, Xiamen 361021, China. E-mail: zjzhang@iue.ac.cn; shchen@iue.ac.cn; Fax: +860592 6190977; Tel: +8605926190529

${ }^{b}$ University of Chinese Academy of Sciences, Beijing 100049, China 
intermediates (e.g., NO). ${ }^{26}$ The reported FNA inhibition mechanisms can vary significantly, because the inhibition effects are highly dependent on the type of organisms present. ${ }^{15}$ Anammox processes, which are widely used for the biological degradation of concentrated ammonia and nitrite streams, are inhibited by nitrites, rather than FNA. ${ }^{27}$

In addition to the inhibition effects of low-concentration FNA on cells in sludge, knowledge on the permeabilization and disruption of cells using a high concentration of FNA is limited and distinguishing the integrity of WAS samples during FNA treatment is a challenge. More importantly, few studies have focused on the direct disintegration of WAS using concentrated FNA. In their pioneering works on nitro-hydrolysis for sludge reduction, Perkins et al. ${ }^{28}$ successfully utilized nitric acid for the rapid hydrolysis of excess sludge at a high temperature $\left(>160{ }^{\circ} \mathrm{C}\right)$ and pressure $(100 \mathrm{psig})$. Their results indicated that the sludge reduction rate reached $75 \%$ with a nitric acid concentration of $11.2 \mathrm{wt} \%$ and excess sludge concentration of $4 \mathrm{wt} \%{ }^{28}$ Further analysis revealed that the initial hydrolysis of sludge can be completed within five minutes. ${ }^{28}$ The majority of the FNA concentrations used during sludge pretreatment in previous reports were maintained at a relatively low level (i.e., below $5 \mathrm{mg} \mathrm{L}^{-1}$ ) with mild reaction conditions, leading to the direct solubility of WAS at approximately $10-20 \%,{ }^{29,30}$ suggesting that some FNA-tolerable bacteria could maintain cellular integrity at these FNA concentrations and treatment conditions. Whether the sludge disintegration by FNA treatment could be improved by more appropriate conditions, especially by treatment with high concentrations of FNA (i.e., above $10 \mathrm{mg} \mathrm{L}^{-1}$ ), remains to be tested.

Therefore, the goals of this study were to (1) optimize the factors that control sludge disintegration, using FNA with a wide range of concentration gradients; (2) investigate the cellular response of some FNA-tolerable cells (e.g., anammox bacteria), which result in the low disintegration effect of WAS in FNA treatment, by surveying the transmembrane ion flow rates using the scanning ion-selective electrode technique (SIET); and (3) assess the permeabilization and disruption of the sludge cells in high concentrations of FNA using flow cytometry (FCM).

\section{Materials and methods}

\subsection{Waste sewage sludge samples}

Waste sewage sludge was collected from a secondary sedimentation tank in a municipal wastewater treatment plant (WWTP) (Jimei WWTP, Xiamen City, China). The supernatant of the sludge samples was removed after precipitation. Then, the concentrated samples were kept refrigerated at $4{ }^{\circ} \mathrm{C}$. The $\mathrm{pH}$, total chemical oxygen demand (TCOD), soluble chemical oxygen demand (SCOD), total solids (TSS), volatile solids (VSS), and heavy metals in the samples are listed in Table 1.

\subsection{Disintegration of sludge with FNA}

The sludge samples $(300 \mathrm{~mL})$ in $1 \mathrm{~L}$ glass bottles were washed three times with tap water and were bubbled with argon to form anaerobic conditions. Then, the $\mathrm{pH}$ and $\mathrm{NO}_{2}{ }^{-}-\mathrm{N}$ concentrations of the samples were adjusted using hydrochloric acid and $\mathrm{NaNO}_{2}$. After stirring at $300 \mathrm{rpm}$ for a certain time, the mixed samples were stored in centrifuge tubes at $4{ }^{\circ} \mathrm{C}$ for follow-up tests.

The most important operating parameters, such as the TSS removal efficiency and COD dissolution efficiency under different $\mathrm{pH}$ levels (i.e., 1.0, 2.0, 3.0, and 4.0) and $\mathrm{NaNO}_{2}$ dosages (i.e., 0, 0.3, 0.9, and $1.5 \mathrm{~g} \mathrm{~g}^{-1} \mathrm{TSS}$ ), were first investigated and compared. Subsequently, the influences of different stirring times (i.e., $0.5,1,3,5,10,24$, and $48 \mathrm{~h}$ ) and temperatures (i.e., $5{ }^{\circ} \mathrm{C}, 20^{\circ} \mathrm{C}, 40^{\circ} \mathrm{C}, 60^{\circ} \mathrm{C}$, and $80{ }^{\circ} \mathrm{C}$ ) were determined using the $\mathrm{pH}$ levels and dosages of $\mathrm{NaNO}_{2}$ identified in the previous step. Thereafter, the sludge reducing efficiencies were calculated under different dosages (i.e., 0, 0.06, 0.12, 0.18, 0.24, and $0.30 \mathrm{~g} \mathrm{~g}^{-1} \mathrm{TSS}$ ) and dosing patterns (i.e., single, double, and quadruple stepwise dosing) of $\mathrm{NaNO}_{2}$.

\subsection{Analysis of cellular stress response towards low concentration FNA shock}

The bacteria in the mixed sludge show different cellular responses to chemical stress, including FNA shock. Polyphosphate accumulating organisms (PAOs) are inhibited by

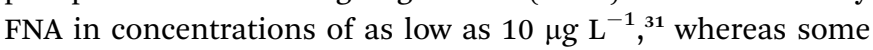

Table 1 Compositions of the sludge samples $(n=3)$

\begin{tabular}{|c|c|c|c|}
\hline Parameters & $\begin{array}{l}\text { Concentration (mg } \mathrm{L}^{-1} \\
\text { except for } \mathrm{pH} \text {, which is dimensionless) }\end{array}$ & Heavy metals & Concentration $\left(\mathrm{mg} \mathrm{kg}^{-1}\right)$ \\
\hline $\mathrm{pH}$ & $7.19 \pm 0.02$ & $\mathrm{Cd}$ & N.D. ${ }^{a}$ \\
\hline SCOD & $22.57 \pm 2.98$ & $\mathrm{Zn}$ & 1340.00 \\
\hline TSS & $(11.69 \pm 0.64) \times 10^{3}$ & $\mathrm{Cu}$ & 170.00 \\
\hline VSS & $(4.32 \pm 0.13) \times 10^{3}$ & $\mathrm{Ni}$ & 26.60 \\
\hline $\mathrm{NH}_{4}^{+}-\mathrm{N}$ & $12.58 \pm 1.29$ & As & 1.10 \\
\hline $\mathrm{TN}^{b}$ & $43.08 \pm 2.93$ & & \\
\hline
\end{tabular}

${ }^{a}$ N.D. refers to not detected. ${ }^{b}$ The basic parameters in the supernatant of the sludge samples. 
FNA-tolerant bacteria survive and show high resistance to hydrolysis, ${ }^{24}$ resulting in low sludge disintegration rates during FNA treatment. In this study, Percoll-purified anammox granules, which can utilize a high concentration of nitrite, were selected for analyzing the transmembrane ionic currents under low-concentration FNA shock. The net flux of the $\mathrm{K}^{+}, \mathrm{Ca}^{2+}$, and $\mathrm{H}^{+}$ions of the purified anammox cells under FNA shock was measured using the SIET system (BIO-001A; Younger USA Sci. \& Tech. Corp.) at Xuyue (Beijing) Sci. \& Tech. Co. Ltd. (http:// www.xuyue.net). ${ }^{32,33}$ Anammox granules were collected from an anammox reactor that has been operating over a long time in our laboratory and purified by Percoll centrifugation according to the method of Strous et $a .^{34}$ The concentration gradients of the selected ions were measured by moving a calibrated microelectrode between two positions $(30 \mu \mathrm{m})$ close to the surface of the anammox granules (approximately $5 \mu \mathrm{m}$ ). The purified anammox granules were fixed on poly-L-lysine-coated slides for $5 \mathrm{~min}$ and equilibrated in a $3 \mathrm{~mL}$ measurement solution $\left(0.1 \mathrm{mM}\right.$ of $\mathrm{CaCl}_{2}, 0.1 \mathrm{mM}$ of $\mathrm{KCl}$, and $0.3 \mathrm{mM}$ of MES at a $\mathrm{pH} 6.0$ ) for $30 \mathrm{~min}$. For the $\mathrm{K}^{+}, \mathrm{Ca}^{2+}$, and $\mathrm{H}^{+}$flux measurements, the ionic flux was recorded for $5 \mathrm{~min}$, and an adequate amount of sodium nitrite was added into the measurement solution to form predesigned FNA concentrations. Subsequently, the ionic flux was continuously recorded using the ion-selective microelectrode for $20 \mathrm{~min}$. The obtained ionic flux rate was calculated from Fick's law of diffusion:

$$
J=-D \frac{\mathrm{d} c}{\mathrm{~d} x}
$$

where $J$ is the ion flux, $\mathrm{d} c / \mathrm{d} x$ represents the ionic concentration gradients, and $D$ is the ion diffusion constant in a particular medium.

\subsection{Analysis of the permeabilization and disruption of sludge cells using a high concentration of FNA by FCM}

Fresh sludge samples were treated with different concentrations of FNA, and the integrity of the cells was analyzed using FCM. To differentiate between the intact and permeabilized bacteria, the cells were stained with SYBR-Green I (1 : 30 dilution of a commercial stock; Invitrogen, USA; $\lambda_{\mathrm{ex}}=495 \mathrm{~nm}, \lambda_{\mathrm{em}}=$ $525 \mathrm{~nm}$ ) diluted in dimethyl sulfoxide (DMSO, Merck, Germany) and propidium iodide (PI, stock solution concentration $1 \mathrm{mg}$ $\mathrm{mL}^{-1}$; Invitrogen, USA; $\lambda_{\text {ex }}=536 \mathrm{~nm}, \lambda_{\mathrm{em}}=617 \mathrm{~nm}$ ). The sludge samples were filtered using a 200-mesh sieve to keep the total suspended cell concentration within $10^{6}$ to $10^{7}$ cells per L. Afterwards, $1 \mathrm{~mL}$ of a bacterial suspension with approximately $10^{6}$ to $10^{7}$ cells per $\mathrm{mL}$ was incubated for $15 \mathrm{~min}$ at room temperature with $10 \mu \mathrm{L}$ of both fluorochromes and away from light. SYBR-Green I dyed all of the cells, whereas PI only dyed the membrane-permeable and dead cells. ${ }^{35}$ In the permeabilized cells, the simultaneous staining with SYBR-1 and PI activated the energy transfer between the fluorochromes. Consequently, intact and permeabilized bacteria emitted green and red fluorescence, respectively.

The cellular states of the sludge samples were analyzed using a FCM instrument (Quanta SC, Beckman Coulter, California).
The signals collected were green and red fluorescence, with a logarithmic gain and forward angle light scattering (FALS), which were related to the cell size. ${ }^{36}$ To eliminate non-bacterial particles and debris, the data acquisition gates were set to green and red fluorescence distributions. At least 10000 cells were analyzed for each sample over a few minutes to provide good statistical data. The accuracy of the staining method and the FCM analysis has been previously evaluated using epifluorescence microscopy. ${ }^{42}$ Finally, the intact, permeabilized, and disrupted cells were identified according to double staining using FCM analysis. ${ }^{37}$

\subsection{Physicochemical analysis methods}

The FNA concentration, COD dissolution efficiency, and TSS removal efficiency were calculated using the following equations: $:^{38,39}$

$$
\begin{gathered}
\mathrm{FNA}\left(\mathrm{mg} \mathrm{L}^{-1}\right)=\frac{47}{14} \times \frac{\mathrm{NO}_{2}^{-}-\mathrm{N}\left(\mathrm{mg} \mathrm{L}^{-1}\right)}{\mathrm{e}^{\frac{-2300}{T}} \times 10^{\mathrm{pH}}}, \\
\text { COD dissolution efficiency }=\frac{\mathrm{SCOD}_{\text {treated }}-\mathrm{SCOD}_{\text {initial }}}{\mathrm{TCOD}_{\text {initial }}}, \\
\text { TSS removal efficiency }=\frac{\mathrm{TSS}_{\text {initial }}-\mathrm{TSS}_{\text {treated }}}{\mathrm{TSS}_{\text {initial }}} .
\end{gathered}
$$

The mixture was first centrifuged at $5000 \mathrm{rpm}$ for $5 \mathrm{~min}$ and filtered using $0.45 \mu \mathrm{m}$ membranes. The concentrations of $\mathrm{NH}_{4}{ }^{+}-\mathrm{N}, \mathrm{NO}_{2}{ }^{-}-\mathrm{N}, \mathrm{NO}_{3}{ }^{-}-\mathrm{N}$, and $\mathrm{PO}_{4}{ }^{3-}-\mathrm{P}$ in the supernatant were measured with a flow injection analyzer (8500 Series 2, QuickChem, USA). The concentrations of TSS and VSS were measured using the standard method. ${ }^{40}$ The COD was analyzed using the colorimetric method (Lian-hua, China). ${ }^{40}$ The practical concentration of COD is defined as the measured concentration minus the concentration of $\mathrm{COD}$, that is, $\mathrm{NO}_{2}{ }^{-}-$ N. Heavy metals were detected using inductively coupled plasma optical emission spectrometry (ICP-OES) (Optima 7000DV, Labconco, USA).

\section{Results and discussion}

\subsection{Performance of FNA on the disintegration of WAS}

In this section, the main influencing factors of the effect of FNA on the disintegration of WAS are analyzed, including the $\mathrm{pH}$, stirring time, temperature, $\mathrm{NaNO}_{2}$ dosage, and $\mathrm{NaNO}_{2}$ dosing method. According to eqn (2) and (3), the TSS removal efficiency and the COD dissolution efficiency were calculated and represent the efficiency of WAS disintegration.

3.1.1 pH. According to eqn (1), the concentration of FNA is related to the amount of $\mathrm{NO}_{2}{ }^{-}-\mathrm{N}$ and the $\mathrm{pH}$ value. At the same $\mathrm{NaNO}_{2}$ dosage level ( $\left.0.3 \mathrm{~g} \mathrm{~g}^{-1} \mathrm{TSS}\right)$, the relationship between the efficiency of WAS disintegration and the $\mathrm{pH}$ values was obtained after $30 \mathrm{~min}$ of batch tests (Fig. 1). The TSS removal efficiency gradually decreased with an increase in the $\mathrm{pH}$ value. When the $\mathrm{pH}$ was 4 , the TSS removal efficiency was below $10 \%$. However, when the pH was 1 , the TSS removal efficiency was $40 \%$ without 

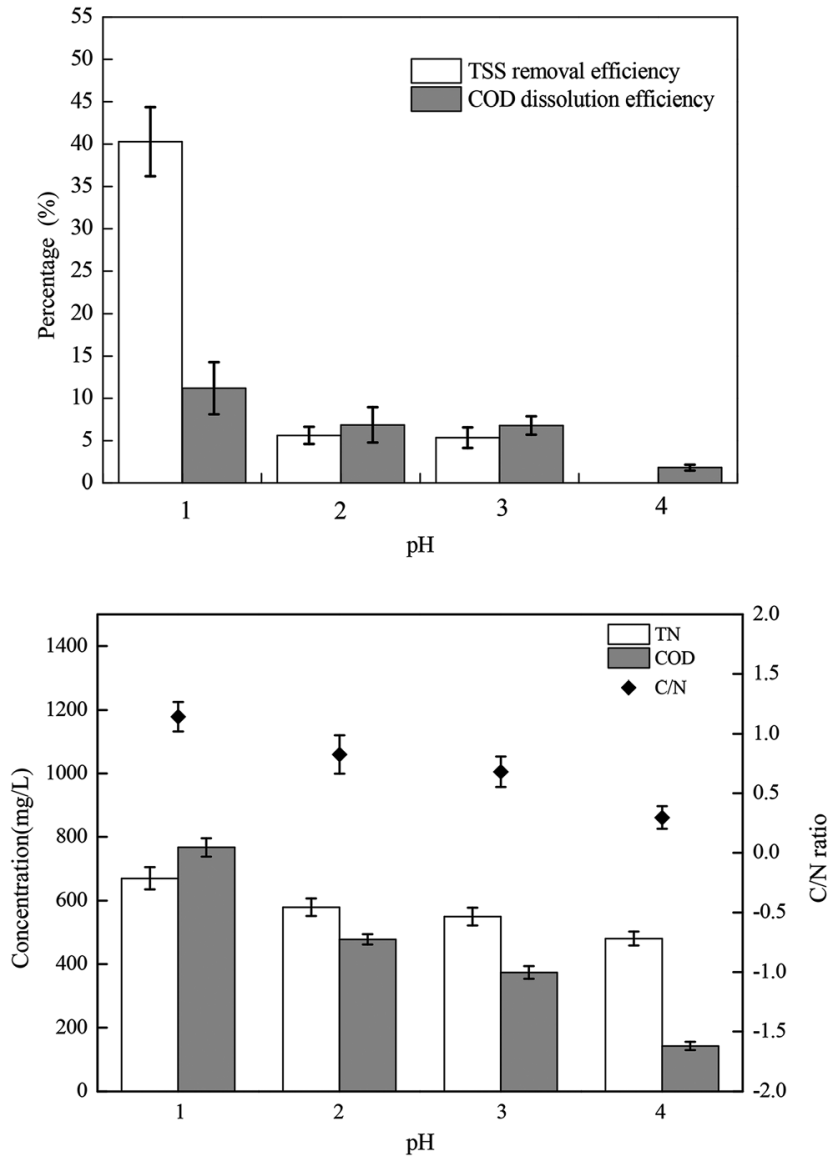

Fig. 1 Sludge disintegration efficiency under different $\mathrm{pH}$ values (the dosage of $\mathrm{NaNO}_{2}$ was $0.3 \mathrm{~g} \mathrm{~g}^{-1} \mathrm{TSS}$ at room temperature $\left(25^{\circ} \mathrm{C}\right)$ ).

$\mathrm{NaNO}_{2}$. Reportedly, the concentrations of soluble sugar and protein increased with a decrease in the $\mathrm{pH}$ value. When the $\mathrm{pH}$ was 2 , the concentrations of soluble polysaccharide and protein in the sludge using acid pretreatment were 3.1 and 9.9 times that of the original sludge, respectively. ${ }^{41}$ Perkins et al. ${ }^{28}$ investigated WAS disintegration by $\mathrm{HNO}_{3}$ and found that TSS removal efficiency is $22-75 \%$ and increases with temperature. Thus, the sky-high concentration of $\mathrm{H}^{+}$could dissolve the cells, and WAS could be dissolved in the polar acid conditions. Fig. 1 shows that like the TSS removal efficiency, the COD dissolution efficiency increased with a decrease in the $\mathrm{pH}$ value. When the $\mathrm{pH}$ values were 1,2 , and 3 , the COD dissolution efficiencies were $11.19 \%, 6.86 \%$, and $6.79 \%$, respectively. However, when the $\mathrm{pH}$ was 4.0 , the COD dissolution efficiency was less than $2 \%$. In the supernatant, the concentrations of COD and TN decreased simultaneously with an increase in the $\mathrm{pH}$ value. Moreover, the $\mathrm{C} / \mathrm{N}$ ratio decreased gradually.

3.1.2 Stirring time. In a previous study, excess sludge was contained in an FNA treatment unit for $24-42 \mathrm{~h}$, and the sludge production was found to be $28 \%$ lower than that of the control used. ${ }^{16}$ Thus, the stirring time was investigated in this batch test. Fig. 2 shows that the TSS removal and COD dissolution efficiencies increased as the stirring time was prolonged from $0.5 \mathrm{~h}$ to $48 \mathrm{~h}$. They tended to be steady after $10 \mathrm{~h}$ at $46.46-$
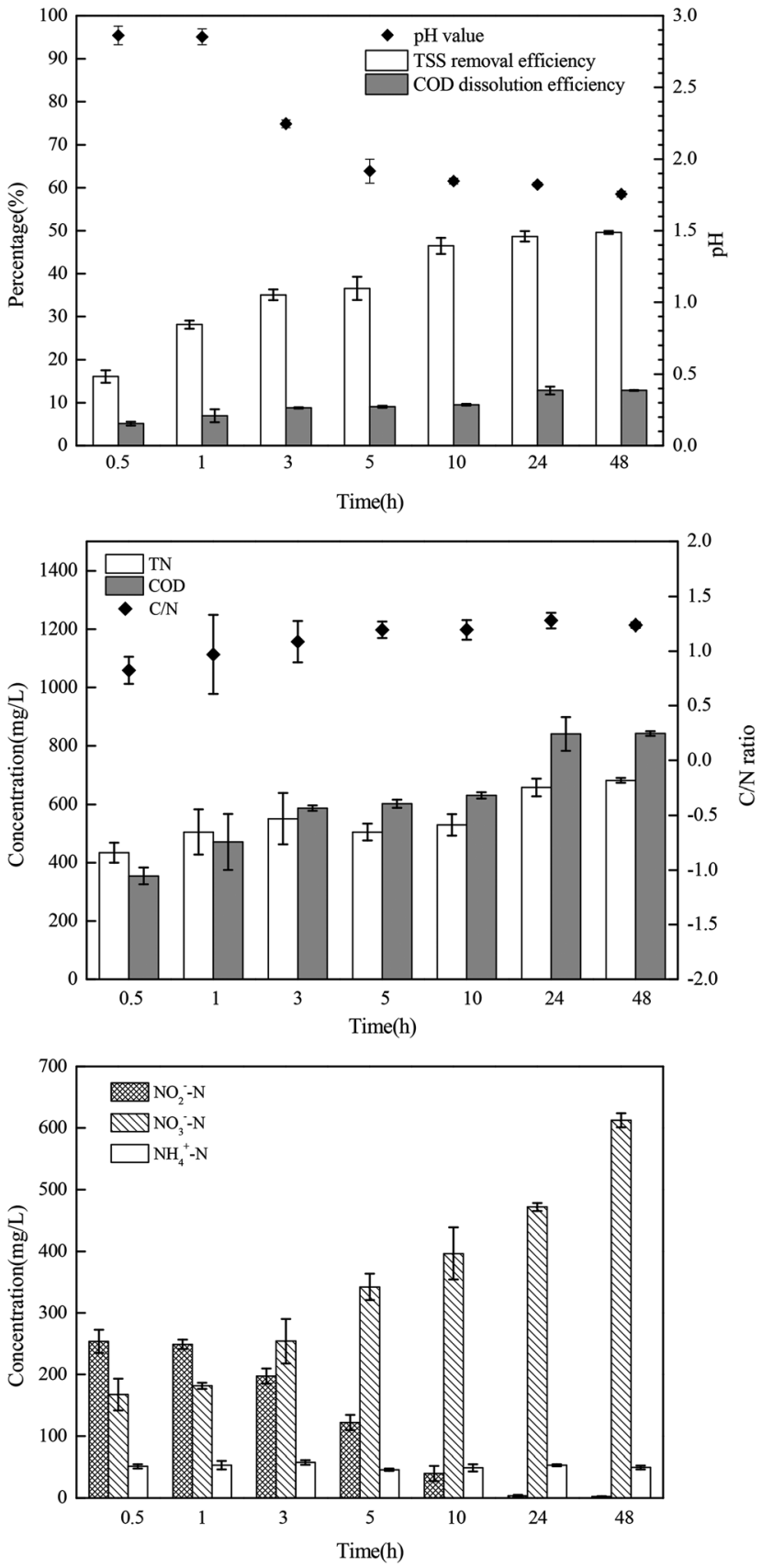

Fig. 2 Sludge disintegration efficiency and the concentration of nitrogen in the supernatant under different stirring times (the dosage of $\mathrm{NaNO}_{2}$ was $0.3 \mathrm{~g} \mathrm{~g}^{-1}$ TSS at room temperature $\left(25^{\circ} \mathrm{C}\right), \mathrm{pH}=3$ ).

$49.60 \%$ and $9.51-12.86 \%$. As Fig. 2 shows, with the extension of time, the concentration of $\mathrm{NO}_{2}{ }^{-}-\mathrm{N}$ decreased, whereas the concentration of $\mathrm{NO}_{3}{ }^{-}-\mathrm{N}$ increased gradually. When the $\mathrm{pH}$ value was 3 , the denitrifying process was inhibited. Thus, the slight differences were owing to the majority of the $\mathrm{NO}_{2}{ }^{-}-\mathrm{N}$ being oxidized after $10 \mathrm{~h}$. In the supernatant, the concentrations of $\mathrm{COD}$ and $\mathrm{TN}$ increased, and the $\mathrm{C} / \mathrm{N}$ ratio changed inconspicuously at approximately 1.0. Thus, it was concluded that stirring for $10 \mathrm{~h}$ was enough. 
3.1.3 Temperature. Thermal treatment is a conventional sludge reduction technique. The flocs in the sludge are destroyed because the extracellular polymeric substance (EPS) is dissolved and hydrolyzed during the thermal treatment. ${ }^{\mathbf{4 2 , 4 3}}$ Previous research, which focused on the nitrolysis treatment of excess sludge, showed that the efficiency of excess sludge conversion decreased from $75 \%$ to $22 \%$ as the temperature dropped below $160{ }^{\circ} \mathrm{C}$. However, when the temperature exceeded $160{ }^{\circ} \mathrm{C}$, the efficiency increased slightly. ${ }^{28}$ As shown in Fig. 3, the TSS removal efficiency increased with an increase in temperature and tended to be steady when the temperature exceeded $40{ }^{\circ} \mathrm{C}$. The TSS removal efficiencies were $43.22 \%$, $46.72 \%$, and $49.29 \%$ at $40{ }^{\circ} \mathrm{C}, 60{ }^{\circ} \mathrm{C}$, and $80{ }^{\circ} \mathrm{C}$, respectively. In the supernatant, the concentration of COD increased, whereas the concentration of TN changed inconspicuously. Therefore, the $\mathrm{C} / \mathrm{N}$ ratio changed inconspicuously at approximately 1.0. An elevated temperature slightly promotes the efficiency of WAS solubilization, however, using excess heat wastes energy. Thus, room temperature $\left(25^{\circ} \mathrm{C}\right)$ was deemed an appropriate temperature to use.

3.1.4 $\mathrm{NaNO}_{2}$ dosage. As shown in Fig. 4, the sludge disintegration efficiency increased with the $\mathrm{NaNO}_{2}$ dosage. However, when the dosage exceeded $0.12 \mathrm{~g} \mathrm{NaNO}_{2}$ per $\mathrm{g}$ TSS, a slight difference was observed between the TSS removal and COD dissolution efficiencies. The TSS removal efficiencies were
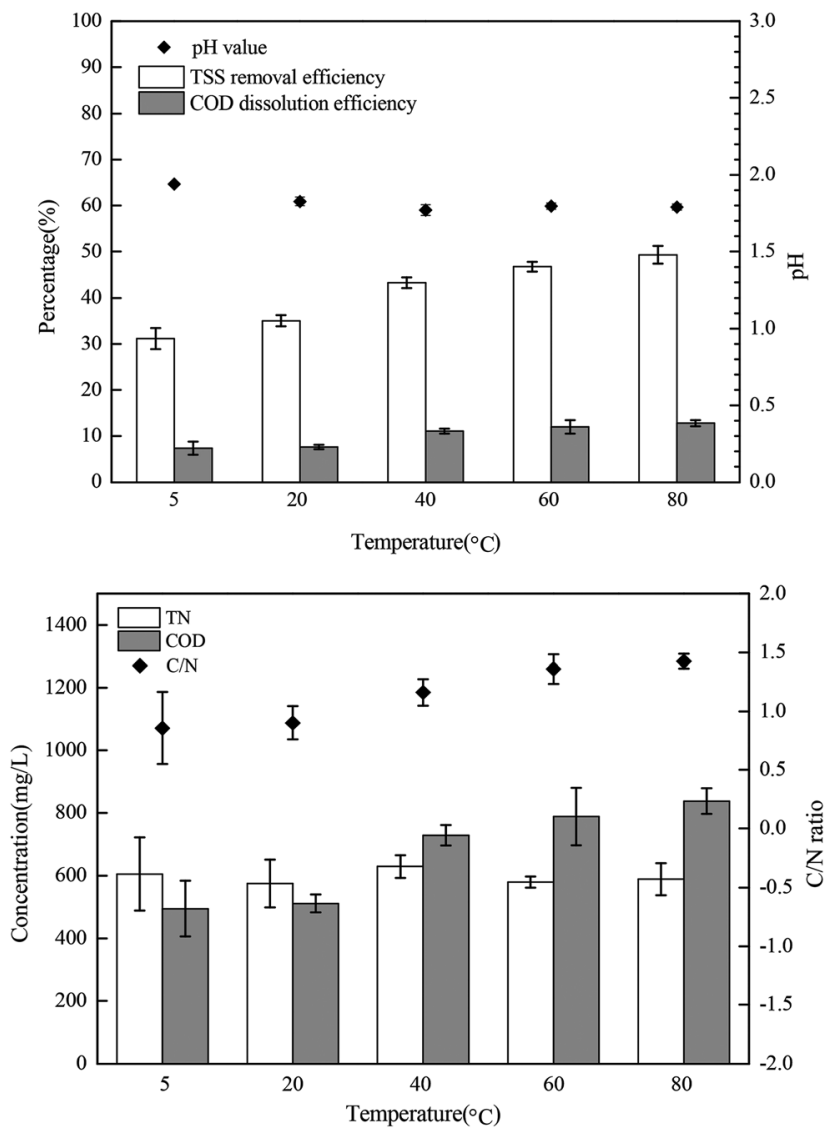

Fig. 3 Sludge disintegration efficiency under different temperatures (the dosage of $\mathrm{NaNO}_{2}$ was $0.3 \mathrm{~g} \mathrm{~g}^{-1}$ TSS, stirring for $10 \mathrm{~h}, \mathrm{pH}=3$ ).
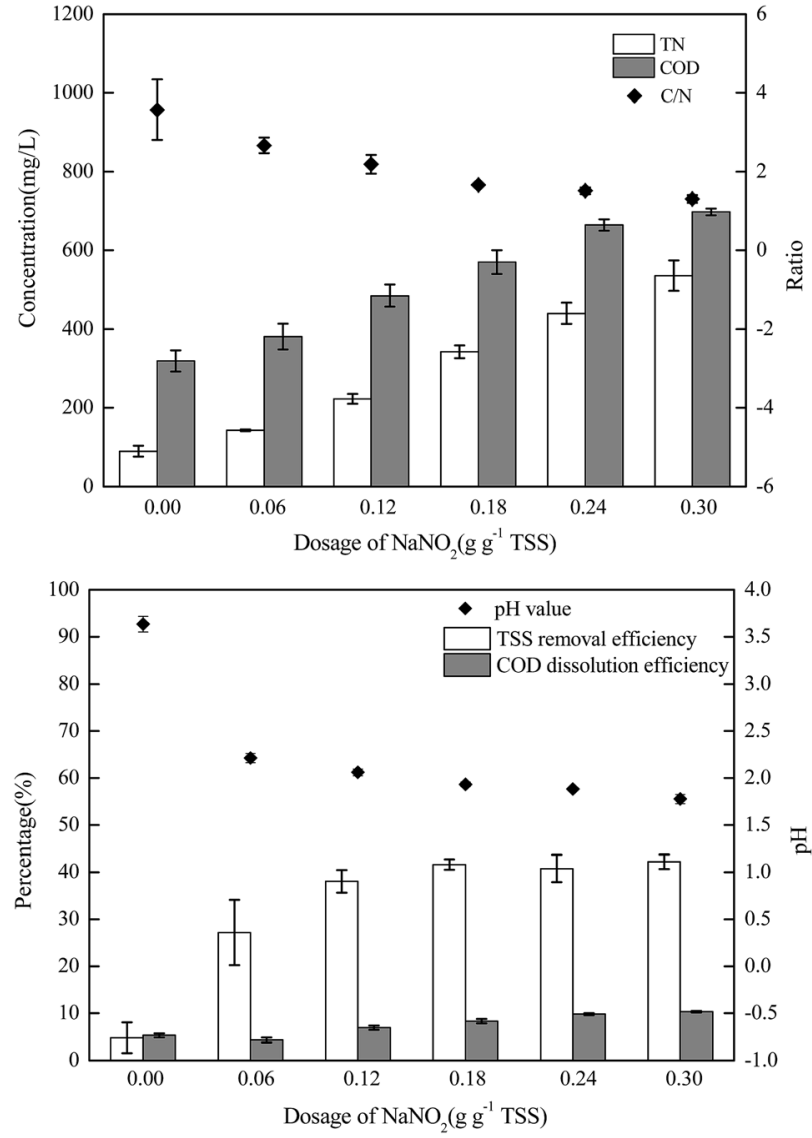

Fig. 4 Sludge disintegration efficiency under different dosages of $\mathrm{NaNO}_{2}$ (stirring for $10 \mathrm{~h}$ at $25^{\circ} \mathrm{C}, \mathrm{pH}=3$ ).

$38.08 \%$ and $41.63 \%$ when the dosages of $\mathrm{NaNO}_{2}$ were 0.12 and $0.18 \mathrm{~g} \mathrm{~g}^{-1} \mathrm{TSS}$, respectively. In the supernatant, the $\mathrm{C} / \mathrm{N}$ ratio decreased gradually as the concentrations of TN increased conspicuously. Thus, the appropriate dosage of $\mathrm{NaNO}_{2}$ was determined to be $0.12 \mathrm{~g} \mathrm{~g}^{-1}$ TSS.

\subsection{Mechanisms of FNA on the solubilization of WAS}

On the basis of the performance of FNA on WAS reduction, the mechanisms of this process are discussed in this section. On the one hand, the typical transmembrane change of the bacteria from the effect of low-concentration FNA was analyzed using SIET. On the other hand, under the high-concentration FNA exposure, the process of cell disintegration was expounded by the FCM results.

3.2.1 Evaluation of the typical transmembrane ion flux of bacteria at low FNA concentration by SIET. In this study, the $\mathrm{K}^{+}$, $\mathrm{Ca}^{2+}$, and $\mathrm{H}^{+}$fluxes on the surface of the purified anammox cell granules (5 $\mu \mathrm{m}$ to $35 \mu \mathrm{m})$, which are considered FNA-tolerant bacteria, were recorded by the SIET system (Fig. 5). In the steady state ( $0 \mathrm{~min}$ to $5 \mathrm{~min}$ ), the anammox granules exhibited a net feeble $\mathrm{K}^{+} / \mathrm{Ca}^{2+}$ efflux, and $\mathrm{H}^{+}$influx through the cell walls after cell equilibration in the measurement solution (Fig. 5). Then, the dosage of sodium nitrite formed a FNA concentration of $0.03 \mathrm{mg} \mathrm{L}{ }^{-1}$. When the granules were subjected to FNA- 

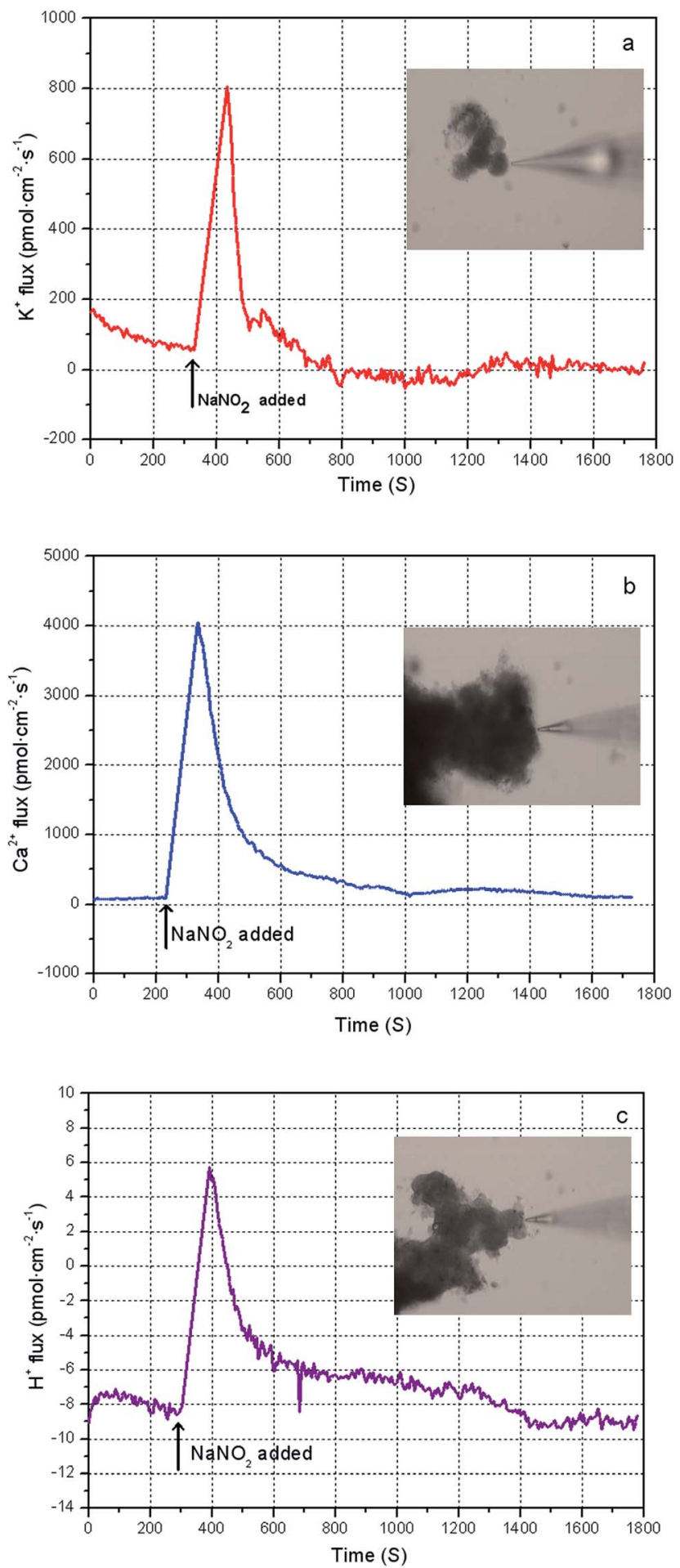

Fig. 5 Effects of FNA shock on transient (a) $\mathrm{K}^{+}$, (b) $\mathrm{Ca}^{2+}$, and (c) $\mathrm{H}^{+}$ fluxes of purified anammox cells. Appropriate amounts of sodium nitrite were added to form a FNA concentration of $0.03 \mathrm{mg} \mathrm{L}^{-1}$. The top-right picture in each figure shows the microelectrode and the anammox granules.

induced shock, the anammox cells showed a dramatic increase in the $\mathrm{K}^{+}, \mathrm{Ca}^{2+}$, and $\mathrm{H}^{+}$effluxes, and the transient (5 min to 10 min) increment of the ion flux returned to the steady state (Fig. 5). The anammox granules could still remove ammonia and nitrite after SIET. Overall, the FNA exposure of anammox cells at a FNA of $0.03 \mathrm{mg} \mathrm{L}^{-1}$ did not result in irreversible ion flux, suggesting that the anammox cells could achieve ion homeostasis under mild FNA or nitrite toxicity.

In theory, the $\mathrm{K}^{+}$-, $\mathrm{Ca}^{2+}$, and $\mathrm{H}^{+}$-dependent regulatory pathways and signaling of cells are considered important cell responses to environmental stress or toxicity. ${ }^{32,44} \mathrm{H}^{+}$transport is carried out by $\mathrm{H}^{+}$ATPase molecules using the energy from the adenosine triphosphate (ATP) hydrolysis in anaerobic bacteria, and viable cells can extrude $\mathrm{H}^{+}$as a physiological defense against stress. ${ }^{45}$ Released $\mathrm{Ca}^{2+}$ ions are considered to reduce $\mathrm{K}^{+}$ efflux and regulate the $\mathrm{K}^{+}$homeostasis of plant or fungi cells under transient environmental stress. ${ }^{44} \mathrm{~A}$ previous study revealed that FNA could act as an uncoupler to disturb the energy generation of cells or mislead the enzyme assemblage. ${ }^{15}$ That is, FNA could enhance the transmembrane proton permeability and thus inhibit ATP synthesis. ${ }^{15}$ Sijbesma et al. ${ }^{24}$ indicated that FNA could diffuse into the cell membrane of the denitrifier $P$. fluorescens derived by enhanced proton permeability. Then, the denitrifier stops releasing protons from the membrane due to the expenditure of the ATP synthesis. Therefore, we deduced that FNA induces the permeabilization of bacteria and eventually leads to cell membrane lysis. This information will benefit our understanding of the FNA inhibition and disintegration of sludge.

3.2.2 Evaluation of the integrity of sludge cells towards a concentration gradient of FNA by FCM. The process of FNA sludge dissolution was analyzed by FCM. According to the membrane integrity, intact and permeabilized cells were identified simultaneously using double fluorescent staining with SYBR-I (which can enter all cells, intact or permeabilized) and PI (a dye which can enter only damaged or permeabilized cells). ${ }^{46,47}$ Membrane integrity in intact cells should include the protection of constituents and the potential capability of metabolic activity and repair. Membranes will eventually decompose if their structures are freely exposed to the environment. Thus, cells without an intact membrane are considered permeabilized and can be classified as dead cells. ${ }^{48}$ Fig. 6 shows that in the example, the FCM cytograms have four regions according to the use of the two dyes (SYBR-1 + PI) and the setting of two thresholds to red and green fluorescence. According to the intensity of the green and red fluorescence emitted, the following regions can be distinguished: intact cells (green signals), dead cells (red signals), permeabilized cells (both red and green signals), and instrument background or noise (red and green signals below the thresholds).

The activated sludge was found to have some small aggregates, which were formed by the gathering of intact and permeabilized cells and appeared fluorescent, emitting red and green signals. Despite the optimization of the disaggregation, some small moderate aggregates remained. The significant FCM cytograms obtained for the most relevant operating conditions when adding different FNA concentrations are summarized. Fig. 7 shows an immediate comparison of the FNA effects on the total cells, distinguished as intact and permeabilized cells. In raw WWTP sludge, the vast number of cells were intact at $\mathrm{pH}=6$. With a decrease in the $\mathrm{pH}$ values, the 


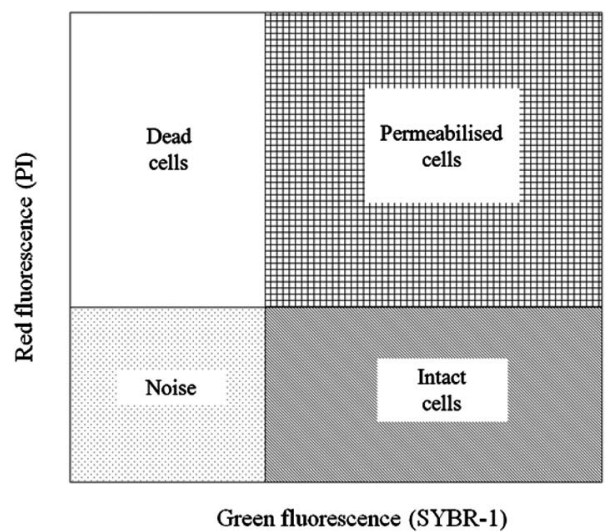

Fig. 6 Example of an FCM cytogram of activated sludge with the indication of the four regions to distinguish intact cells and permeabilized cells.

proportion of intact cells decreased gradually, whereas the proportion of permeabilized cells and cell fragments increased obviously. At $\mathrm{pH}$ values of $4.5,4.0$, and 3.5 , the concentrations of FNA were found to be $0.27,8.86$, and $82.71 \mathrm{mg} \mathrm{L}^{-1}$, respectively. Meanwhile, several dissolved cell fragments and other particles were detected. Peer studies have shown that microbial dissimilation is restrained when the FNA concentration is within $1.3-2.1 \mathrm{mg} \mathrm{L}^{-1}{ }^{38}$ Thus, the cells in the sludge would be hydrolyzed owing to the high FNA concentration at low $\mathrm{pH}$.

The mechanisms of the minimal amount of FNA inhibiting the cellular metabolism and the large amount of FNA decomposing the cells remains unclear. Owing to the FNA effect, the nitrite oxidizing bacteria (NOB) in the sludge in the experimental group ( $\mathrm{FNA}=1.35 \mathrm{mg}$ of $\mathrm{HNO}_{2}-\mathrm{N} \mathrm{L}^{-1}$ ) was reduced by $80 \%$ of that of the control group. ${ }^{49}$ Jabari et al. ${ }^{50}$ studied the microbial activity of the phosphorus removal of microorganisms under different FNA concentrations and found that FNA concentration is one of the most important factors of phosphorus removal efficiency. Therefore, FNA has a universal inhibitory effect on biological metabolic processes..$^{51-54}$ Further mechanism studies have shown that these inhibitory effects restrain ATP metabolic processes, such as the active transport process of the cell membrane, the process of oxygen intake, and oxidative phosphorylation..$^{52,55-57}$ However, reports on the mechanism of membrane decomposition under high FNA concentrations are few. Like FNA sludge reduction, sludge reduction based on a high temperature and the use of high pressure nitric acid has been industrialized. ${ }^{28}$ However, FNA sludge reduction has obvious advantages in terms of energy consumption compared with this method.
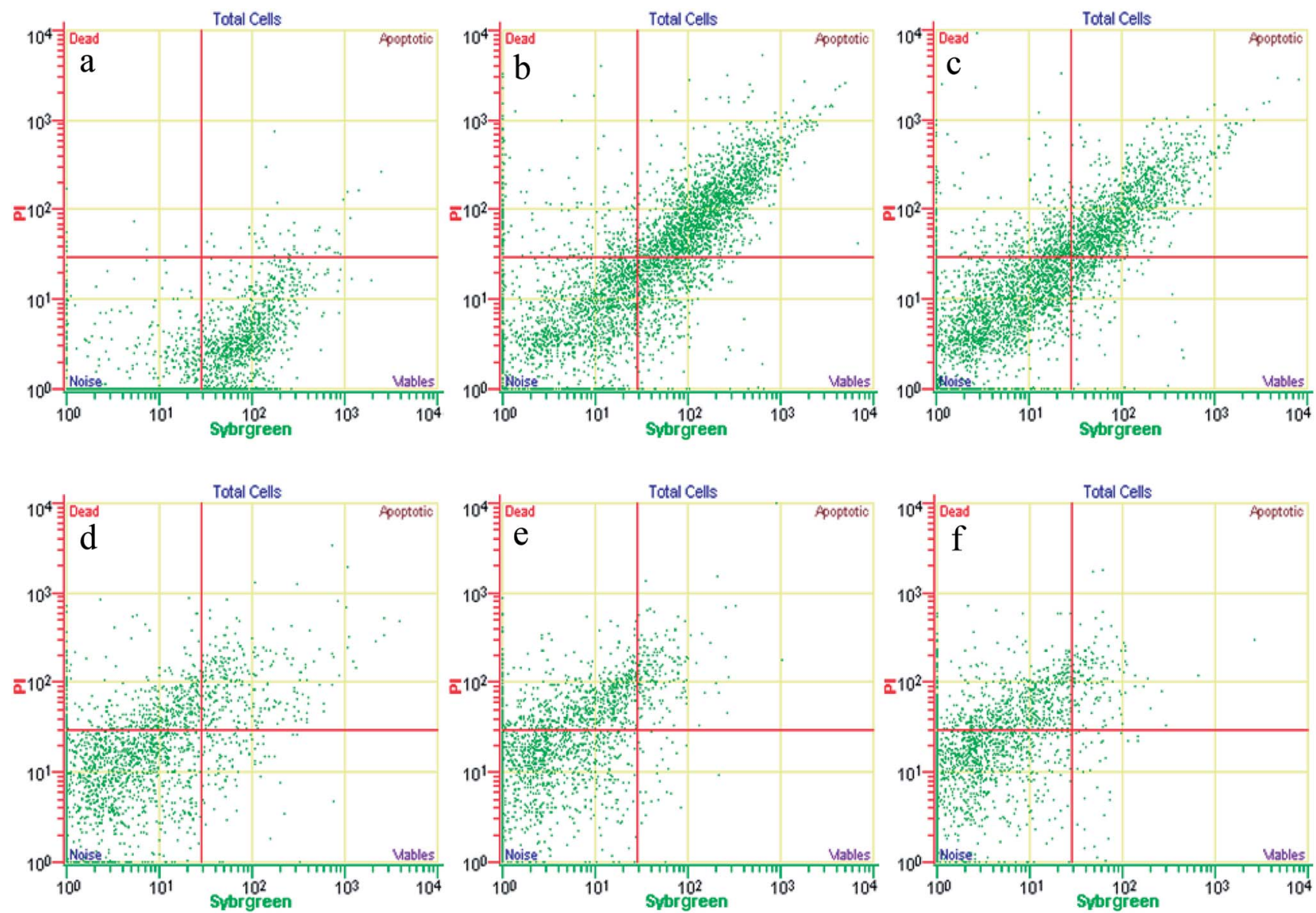

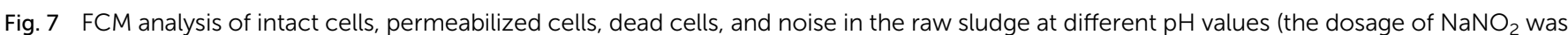
50 mM. (a) $\mathrm{pH}=6.00$; (b) $\mathrm{pH}=5.50$; (c) $\mathrm{pH}=5.00$; (d) $\mathrm{pH}=4.50$; (e) $\mathrm{pH} 4.00$; (f) $\mathrm{pH}=3.50$ ). 


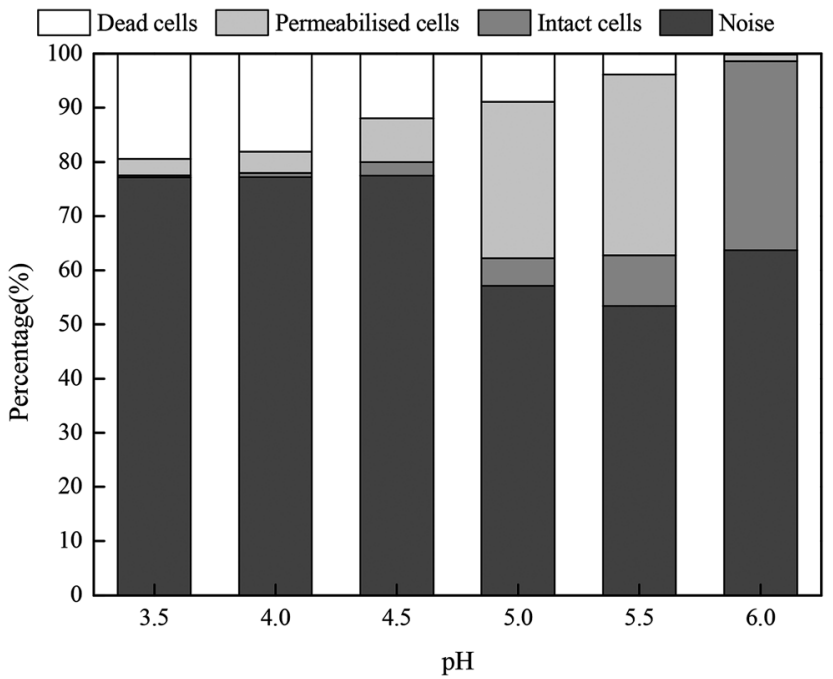

Fig. 8 Proportion of intact cells, permeabilized cells, dead cells, and noise at different $\mathrm{pH}$ values.

Fig. 8 shows the proportions of dead, permeabilized and intact cells in fresh sludge at different $\mathrm{pH}$ values. When the $\mathrm{pH}$ value was 6.0 , the living cells accounted for $34.92 \%$, whereas the proportions of dead and permeabilized cells were only $0.21 \%$ and $1.21 \%$, respectively. The proportion of intact cells gradually declined with the $\mathrm{pH}$ values, whereas the proportion of dead and permeabilized cells increased. When the $\mathrm{pH}$ value was 3.5, the percentages of intact, permeabilized and dead cells were $0.37 \%, 3.03 \%$ and $19.39 \%$, respectively. Moreover, the noncellular structure impurities and particles in the municipal sludge were counted by FCM. Thus, the noise not only included cell debris, but also other impurity particles.

\section{Conclusions}

In this study, a series of batch tests were conducted to evaluate direct sludge disintegration using concentrated FNA. The cell response of transmembrane ion flow rates toward lowconcentration FNA shock was surveyed using a SIET system. The permeabilization and disruption of bacteria in sludge flocs under a high concentration of FNA were analyzed by FCM. The main conclusions can be summarized as follows:

(1) Sludge disintegration efficiency was superior when the sludge was exposed to FNA for $10 \mathrm{~h}$ at $25{ }^{\circ} \mathrm{C}$. When the dosage of $\mathrm{NaNO}_{2}$ was $0.12 \mathrm{~g} \mathrm{~g}^{-1}$ TSS and the $\mathrm{pH}$ was 3.0 (FNA = $20.94 \mathrm{mg} \mathrm{L}^{-1}$ ), the TSS removal and COD dissolution efficiencies were prominent at $38 \%$ and $7 \%$, respectively.

(2) In low FNA concentrations, some FNA-tolerable cells increased the $\mathrm{K}^{+}, \mathrm{Ca}^{2+}$, and $\mathrm{H}^{+}$effluxes and finally achieved ion homeostasis. This phenomenon may cause the cells to maintain cytoactivity and integrity under low-concentration FNA shock.

(3) In high FNA concentrations, the cells in the sludge flocs are disrupted within 30 min when the FNA exceeds $8 \mathrm{mg} \mathrm{L}^{-1}$ $(\mathrm{pH}=4.0)$.

\section{Conflicts of interest}

There are no conflicts to declare.

\section{Acknowledgements}

This work is supported by the National Science and Technology Major Project of China under Grant No. 2016ZX05060-022, the National Natural Science Foundation of China under Grant No. 51208491, and the Frontier Research Projects of IUE-CAS under Grant No. IUEQN201304. We wish to thank the anonymous reviewers for their valuable suggestions on revising the work.

\section{References}

1 Z. W. He, C. X. Yang, L. Wang, Z. C. Guo, A. J. Wang and W. Z. Liu, Chem. Eng. J., 2016, 290, 125-135.

2 H. Liu, Y. Wang, Y. Bo, Y. Zhu, F. Bo and L. He, Bioresour. Technol., 2016, 218, 92-100.

3 Y. Wei, R. T. Van Houten, A. R. Borger, D. H. Eikelboom and Y. Fan, Water Res., 2003, 37, 4453-4467.

4 D. Wang, Y. Wang, Y. Liu, H. H. Ngo, Y. Lian, J. Zhao, F. Chen, Q. Yang, G. Zeng and X. Li, Bioresour. Technol., 2017, 234-456.

5 C. P. Chu, B. V. Chang, G. S. Liao, D. S. Jean and D. J. Lee, Water Res., 2001, 35, 1038-1046.

6 J. Abelleira, S. I. Pérezelvira, J. R. Portela, J. Sánchezoneto and E. Nebot, Environ. Sci. Technol., 2012, 46, 6158.

7 M. D. Gracia, P. Grau, E. Huete, J. Gómez, J. L. García-Heras and E. Ayesa, Water Res., 2009, 43, 4626-4642.

8 W. Wang, H. Hou, S. Hu and X. Gao, Bioresour. Technol., 2010, 101, 1715.

9 V. K. Tyagi and S. L. Lo, Bioresour. Technol., 2012, 119, 105113.

10 C. Liu, Z. Lei, Y. Yang, H. Wang and Z. Zhang, Bioresour. Technol., 2013, 137, 57.

11 X. Zhang, H. Lei, K. Chen, Z. Liu, H. Wu and H. Liang, Chem. Eng. J., 2012, 210, 467-474.

12 G. Jiang, O. Gutierrez and Z. Yuan, Water Res., 2011, 45, 3735-3743.

13 L. Yingyu, L. Ye, Q. L. Wang, S. H. Hu, P. Maite and Z. G. Yuan, Chem. Eng. J., 2015, 259, 62-69.

14 W. Qilin, J. Guangming, Y. Liu, P. Maite and Y. Zhiguo, Water Res., 2014, 62, 202-210.

15 Y. Zhou, A. Oehmen, M. Lim, V. Vadivelu and W. J. Ng, Water Res., 2011, 45, 4672-4682.

16 Q. Wang, L. Ye, G. Jiang and Z. Yuan, Water Res., 2013, 47, 3663-3672.

17 D. Wang, Q. Wang, A. E. Laloo and Z. Yuan, Environ. Sci. Technol., 2016, 50, 7425.

18 M. Pijuan, Q. Wang, L. Ye and Z. Yuan, Bioresour. Technol., 2012, 116, 92-98.

19 D. Wang, Q. Fu, Q. Xu, Y. Liu, H. H. Ngo, Q. Yang, G. Zeng, X. Li and B. J. Ni, Bioresour. Technol., 2017, 244, 920.

20 D. Wang, Q. Wang, L. Andrew, Y. Xu, P. L. Bond and Z. Yuan, Sci. Rep., 2016, 6, 25547. 
21 Q. Wang, L. Ye, G. Jiang, P. D. Jensen, D. J. Batstone and Z. Yuan, Environ. Sci. Technol., 2013, 47, 11897.

22 J. Zhao, D. Wang, X. Li, Q. Yang, H. Chen, Y. Zhong and G. Zeng, Water Res., 2015, 78, 111.

23 X. Li, J. Zhao, D. Wang, Q. Yang, Q. Xu, Y. Deng, W. Yang and G. Zeng, Chemosphere, 2016, 144, 160-167.

24 W. F. Sijbesma, J. S. Almeida, M. A. Reis and H. Santos, Biotechnol. Bioeng., 1996, 52, 176-182.

25 J. W. Park, Arch. Pharmacal Res., 1993, 16, 1-5.

26 S. Carlsson, N. P. Wiklund, L. Engstrand, E. Weitzberg and J. O. Lundberg, Nitric Oxide, 2001, 5, 580-586.

27 T. Lotti, V. D. S. Wr, R. Kleerebezem, C. Lubello and M. C. van Loosdrecht, Water Res., 2012, 46, 2559-2569.

28 L. W. Perkins, K. T. Klasson, R. M. Counce and P. R. Bienkowski, Ind. Eng. Chem. Res., 2003, 42, 3544-3548.

29 Q. Wang, W. Wei, Y. Gong, Q. Yu, Q. Li, J. Sun and Z. Yuan, Sci. Total Environ., 2017, 587-588, 510.

30 M. Bin, P. Yongzhen, W. Yan, L. Baikun, B. Peng and W. Yayi, Bioresour. Technol., 2015, 179, 20-25.

31 Y. Zhou, L. Ganda, M. Lim, Z. Yuan and W. J. Ng, Bioresour. Technol., 2012, 116, 340-347.

32 G. M. Zeng, A. W. Chen, G. Q. Chen, X. J. Hu, S. Guan, C. Shang, L.-H. Lu and Z. J. Zou, Environ. Sci. Technol., 2012, 46, 7818-7825.

33 A. Lin, G. C. Wang and W. Q. Zhou, Physiol. Plant., 2013, 148, 582-589.

34 M. Strous, J. A. Fuerst, E. H. M. Kramer, S. Logemann, G. Muyzer, K. T. V. D. Passchoonen, R. Webb, J. G. Kuenen and M. S. M. Jetten, Nature, 1999, 400, 446-449.

35 G. Ziglio, G. Andreottola, S. Barbesti, G. Boschetti, L. Bruni, P. Foladori and R. Villa, Water Res., 2002, 36, 460-468.

36 P. Foladori, A. Quaranta and G. Ziglio, Water Res., 2008, 42, 3757-3766.

37 P. Foladori, S. Tamburini and L. Bruni, Water Res., 2010, 44, 4888-4899.

38 T. Yamamoto, K. Takaki, T. Koyama and K. Furukawa, Bioresour. Technol., 2008, 99, 6419.
39 C. J. Cheng, P. K. A. Hong and C. F. Lin, Chemosphere, 2012, 87, 637.

40 SEPA, Editorial Committee of "monitoring and analytical methods of water and wastewater", China Environmental Science Press, Beijing, 4th edn, 2002.

41 L. Changqing, Z. Youcai, Z. Jiangshan, C. Wenhua and N. Dongjie, Acta Sci. Circumstantiae, 2008, 28, 2006-2011.

42 M. P. J. Weemaes and W. H. Verstraete, J. Chem. Technol. Biotechnol., 2010, 73, 83-92.

43 E. Neyens and J. Baeyens, J. Hazard. Mater., 2003, 98, 51.

44 J. Li, S. Bao, Y. Zhang, X. Ma, M. Mishraknyrim, J. Sun, G. Sa, X. Shen, A. Polle and S. Chen, Plant Physiol., 2012, 159, 1771.

45 L. Shabala, B. Budde, T. Ross, H. Siegumfeldt, M. Jakobsen and T. Mcmeekin, Appl. Environ. Microbiol., 2002, 68, 17941802.

46 G. Ziglio, G. Andreottola, S. Barbesti, G. Boschetti, L. Bruni, P. Foladori and R. Villa, Water Res., 2002, 36, 460-468.

47 P. Foladori, B. Laura, A. Gianni and Z. Giuliano, Water Res., 2007, 41, 235-243.

48 G. Nebe-Von-Caron, P. J. Stephens, C. J. Hewitt, J. R. Powell and R. A. Badley, J. Microbiol. Methods, 2000, 42, 97-114.

49 Q. Wang, L. Ye, G. Jiang, S. Hu and Z. Yuan, Water Res., 2014, 55, 245-255.

50 P. Jabari, G. Munz, Q. Yuan and J. A. Oleszkiewicz, Chem. Eng. J., 2016, 287, 38-46.

51 C. Glass, J. A. Silverstein and J. Oh, Water Environ. Res., 1997, 69, 1086-1093.

52 V. M. Vadivelu, J. Keller and Z. Yuan, Biotechnol. Bioeng., 2006, 95, 830-839.

53 Y. Zhou, M. Pijuan and Z. Yuan, Biotechnol. Bioeng., 2007, 98, 903.

54 L. Zhang, J. C. Yang and K. Furukawa, J. Biosci. Bioeng., 2010, 110, 441-448.

55 Y. Zhou, L. Ganda, M. Lim, Z. Yuan, S. Kjelleberg and W. J. Ng, Appl. Microbiol. Biotechnol., 2010, 88, 359-369.

56 L. Ye, M. Pijuan and Z. Yuan, Water Res., 2010, 44, 29012909.

57 M. Pijuan, L. Ye and Z. Yuan, Water Res., 2010, 44, 6063. 